\title{
ANALISIS YANG MEMPENGARUHI NIAT BERTRANSAKSI ONLINE E-COMMERCE SHOPEE DI KOTA DENPASAR PROVINSI BALI
}

\section{ANALYSIS THAT AFFECTS INTENTION TO TRANSACT ONLINE AT SHOPEE E- COMMERCE IN DENPASAR CITY, BALI PROVINCE}

I Nyoman Wahyu
Widiana $^{1}$
Universitas
Mahendradatta,
Indonesia ${ }^{1}$
email:
wahyuwidiana94@gma
il.com

11.com

IJI Publication p-ISSN: 2774-1907 e-ISSN: 2774-1915 Vol. 1, No. 2, pp. 70-81 Maret 2021

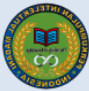

Unit Publikasi Ilmiah Intelektual Madani Indonesia
Abstrak: Perubahan pola perilaku dan kebutuhan konsumen mengikuti perkembangan teknologi dan arus informasi menjadikan lebih bertingkah laku praktis. Konsumen membutuhkan kecepatan dan ketepatan dalam pemenuhan kebutuhan. E-commerce adalah jawaban atas kecepatan dan ketepatan pemenuhan kebutuhan konsumen yang menawarkan keunggulan kompetitifnya yakni lebih hemat waktu, dan praktis.Tujuan penelitian ini untuk menganalisis pengaruh keamanan, kepercayaan, dan privasi terhadap niat bertransaksi secara online di e-commerce Shopee secara simultan dan parsial. Penelitian ini menggunakan metode kuantitatif dengan pendekatan survei. Penarikan sampel penelitian menggunakan accidental sampling, dengan sampel penelitian sebanyak 110 responden yang merupakan konsumen pengguna E-commerce Shopee di Kota Denpasar Provinsi Bali. Hasil penelitian diolah dengan menggunakan SPSS kemudian dianalisis dengan menggunakan analisis regresi linear berganda. Hasil analisis regresi linier berganda uji $\mathrm{F}$ (simultan), disimpulkan bahwa variabel keamanan, kepercayaan, dan privasi memiliki pengaruh terhadap variabel niat bertransaksi online di e-commerce Shopee di Kota Denpasar Provinsi Bali, hasil analisis uji t disimpulkan bahwa variabel keamanan, kepercayaan, dan privasi berpengaruh signifikan secara parsial terhadap variabel niat bertransaksi secara online di e-commerce Shopee di Kota Denpasar Provinsi Bali. Artinya, semakin tinggi tingkat keamanan, kepercayaan, privasi yang dilakukan oleh e-commerce Shopee maka semakin tinggi niat bertransaksi online di e-commerce Shopee, dan sebaliknya semakin rendah tingkat keamanan, kepercayaan, privasi yang dilakukan oleh e-commerce Shopee maka semakin rendah pula niat bertransaksi online di e-commerce Shopee. Oleh karena itu untuk meningkatkan niat bertransaksi online di e-commerce Shopee, maka pihak perusahaan memperhatikan faktor-faktor keamanan, kepercayaan, dan privasi dalam menerapkan dan mengembangkan transaksi e-commerce.

Kata Kunci: E-Commerce, Keamanan, Kepercayaan, Privasi dan Niat Bertransaksi.

Abstract: Changes in behavior patterns and consumer needs following technological developments and the flow of information make behaving more practically. Consumers need speed and accuracy in fulfilling their needs. E-commerce is the answer to the speed and accuracy of meeting consumer needs that offers competitive advantages, namely, it is more time-efficient and practical. The purpose of this study is to analyze the effect of security, trust and privacy on the intention to transact online in e-commerce Shopee simultaneously and partially. This study uses a quantitative method with a survey approach. Withdrawal of research samples usingaccidental sampling, with a research sample of 110 respondents who are consumers of Shopee E-commerce users in Denpasar City, Bali Province. The research results were processed using SPSS and then analyzed using multiple linear regression analysis. The results of multiple linear regression analysis of the F test (simultaneous), it is concluded that the variables of security, trust, and privacy have an influence on the variable of online transaction intentions in Shopee e-commerce in Denpasar City, Bali Province, the results of the $t$ test analysis concluded that the variables of security, trust, and Privacy has a partially significant effect on the intention to transact online at Shopee's e-commerce in Denpasar City, Bali Province. This means that the higher the level of security, trust, and privacy carried out by Shopee e-commerce, the higher the intention to transact online in Shopee's ecommerce, and conversely the lower the level of security, trust, privacy carried out by Shopee ecommerce, the lower it is. intentions to transact online in the e-commerce Shopee.pay attention to security, trust, and privacy factors in implementing and developing e-commerce transactions.

Keywords: E-commerce, Security, Trust, Privacy and Transaction Intention.

\section{PENDAHULUAN}

Perkembangan dunia pemasaran kini telah mengalami perkembangan yang sangat pesat, salah satunya dengan penggunaan internet. Penggunaan internet untuk iklan produk sebagai sarana promosi memberikan informasi pada konsumen secara langsung tanpa melalui perantara. Online store amerupakan salah satu dari aplikasi business to consumer (B2C) telah menyediakan produk 
dan jasa melalui internet bagi konsumen. Manfaat online store bagi konsumen adalah dapat berbelanja tanpa meninggalkan rumah atau membandingkan harga suatu produk dari satu toko ke toko lainnya hanya dengan mengklik beberapa tombol. Pemahaman mengenai penggunan teknologi informasi adalah permasalahan kompleks karena adanya perbedaan karakteristik yang dipengaruhi oleh beberapa faktor, misalnya aspek perilaku. Pertimbangan perilaku tersebut perlu mendapat perhatian khusus dalam konteks penerapan teknologi informasi. Bagi penjual kepuasan pelanggan adalah salah satu permasalahan yang sangat penting. Banyak hal dalam mempengaruhi kepuasan pelanggan dalam berbelanja, yakni tersedianya informasi lengkap produk, jaminan atau garansi, layanan yang baik, dan kenyamanan dalam berbelanja. Perkembangan ini mendorong penjual produk konvensional ikut dalam memasarkan produknya melalui internet.

Transaksi bisnis melalui internet di Indonesia kini menjadi sebuah fenomena yang sedang populer dan menimbulkan peningkatan penggunaan internet. Selain dibidang bisnis meningkatnya pengguna internet juga memberikan dampak bagi perilaku masyarakat dalam melakukan pembelian, baik pembelian barang maupun jasa. Hal tersebut dikarenakan banyak perusahaan yang mempromosikan produknya di internet melalui e-commerce. E-Commerce adalah teknologi, proses, dan praktek yang dapat melakukan transaksi tanpa menggunakan kertas sebagai sarana mekanisme. E-commerce telah memberikan pengaruh besar terhadap pertumbuhan tata sosial dan ekonomi masyarakat. E-commerce merupakan bagian penting dari sektor bisnis swasta (private) maupun umum (publik). Ecommerce kini telah memberikan pengaruh besar terhadap pertumbuhan tata sosial dan ekonomi masyarakat. Terdapat banyak jenis $e$ commerce yang berkembang di dunia, namun hanya ada beberapa jenis e-commerce yang berkembang di Indonesia.

Kepuasan atau ketidakpuasan pelanggan adalah konsep utama marketing dan sistem informasi. Pelanggan dapat membuat keputusan untuk membeli suatu barang berdasarkan kebutuhan. Jika pelanggan tertarik dengan pelayanan yang diberikan ataupun fasilitas-fasilitas yang ada, maka ada keinginan untuk memutuskan membeli barang pada tempat yang sama di kemudian hari. Hasil survey Master Card Internasional tahun 2006 menyimpulkan sebagian besar pelanggan yang melakukan pembelian online tidak terlalu memperdulikan potongan harga, tetapi lebih mementingkan kenyamanan dalam berbelanja. Indonesia semakin melek akan teknologi internet dan menjadikan negara Indonesia memiliki pasar konsumen dalam bidang internet tinggi, sehingga akan meningkat seiring dengan bertumbuhnya jumlah penetrasi internet di Indonesia (Nugroho, 2016). Muhsin (2017), untuk menunjang kehadiran e-commerce, website adalah komponen penting pengguna internet yang ingin berbelanja secara online. Kualitas website e-commerce dapat berpengaruh pada banyaknya pelanggan untuk belanja online pada e-commerce tersebut, untuk mengetahui bagus atau tidaknya kualitas website terdapat sebuah standar (Fauziah,2018).

E-commerce merupakan kegiatan bisnis yang berkaitan dengan konsumen (consumers), manufaktur (manufactures), service providers dan pedagang perantara (intermediaries) dengan menggunakan jaringan komputer (computer networks) yaitu internet. Saputra (2017), ecommerce merupakan salah satu jenis mekanisme transaksi bisnis dengan menggunakan internet sebagai media pertukaran barang atau jasa. E-commerce dapat membawa peluang bisnis yang besar (seperti penjualan produk dan penyediaan layanan online) dan pertumbuhan pendapatan. 
Salah satu jenis e-commerce yang saat ini berkembang pesat di Indonesia adalah $e$ commerce jenis marketplace. Marketplace adalah tempat berkumpulnya penjual dan pembeli dalam sebuah situs website. Konsep ecommerce kini membuat biaya transportasi, marketting, dan operasional menjadi lebih rendah dan harga dapat ditekan menjadi murah, sehingga akan dapat memicu peningkatan volume penjualan. Konsep ecommerce sangat efektif dan efisien, bisa menghemat waktu dan tempat, dengan dukungan $\mathrm{WiFi}$ yang semakin banyak dan meningkatnya perkembangan jaringan dari provider yang semakin bagus. Namun, disamping kemudahan bertransaksi secara online, ada beberapa hambatan yang dihadapi oleh penguna sistem e- commerce.

Hambatan yang sering dihadapi oleh penguna sistem e-commerce, seperti kurangnya kepercayaan antara penjual dan pembeli, penyalahgunaan informasi pribadi yang diberikan pembeli kepada penjual, belum terbiasanya berbelanja dengan menggunakan katalog, model website yang sulit dipahami, pengiriman barang masih ditakutkan hilang di jalan, barang rusak saat pada pengiriman dan barang yang dipesan tidak sesuai dengan keinginan konsumen. Adapun potensi kejahatan yang biasa terjadi salah satu contohnya penipuan yang biasa terjadi disekitar kita seperti uang telah ditransfer tapi barang tidak sampai ditangan konsumen atau tidak barang yang dikirim palsu bukan original. Hal ini mengakibatkan konsumen membatalkan niatnya untuk melakukan transaksi pembelian secara online.

Awalnya belanja melalui internet tidak terlalu diminati karena takut tertipu, tidak memuaskan, pengiriman lama serta sistem pemesanan yang rumit. Namun belakangan ini, berbagai website (online store) telah menyediakan fasilitas yang dapat mempermudah serta memberikan jaminan kepercayaan dan kepuasan bagi konsumen sehuingga konsumen berani memutuskan untuk melakukan aktifitas belanja secara online. Ananta (2006), kecepatan perkembangan teknologi, komunikasi, dan informasi dan e-commerce memungkinkan konsumen untuk membeli produk dan jasa secara online. Perusahaan saat ini bersaing dalam menyediakan layanan online untuk meningkatkan jumlah pelanggan belanja online (Rofiq, 2007).

Web atau situs merupakan media penting bagi kepentingan bisnis untuk menyebarkan informasi dan meraih pelanggan di internet, yang merupakan salah satu dari strategi pemasaran. Pemasaran merupakan proses sosial individu atau kelompok guna mendapatkan apa yang mereka butuhkan dan inginkan dengan cara menciptakan, menawarkan, serta secara bebas mempertukarkan produk dan jasa yang bernilai dengan pihak lain (Kotler, 2007:10). Salah satu web atau situs jual beli yang saat ini mendominasi pasar online di Indonesia adalah Shopee. Shopee adalah sebuah platform yang dirancang khusus dalam menyuguhkan pengalaman berbelanja online yang mudah, praktis, aman dan cepat melalui sistem pembayaran dan dukungan logistik yang tersebar di seluruh Indonesia. Shopee mempunyai tujuan dan maksud untuk berkembang menjadi e-commerce pilihan utama di Indonesia. Shopee mempunyai ragam pilihan kategori produk, mulai dari Elektronik, Perlengkapan Rumah, Kesehatan, Kecantikan, Ibu \& Bayi, Fashion hingga Perlengkapan Olahraga.

Shopee merupakan anak perusahaan dari Sea Group, pertama kali diluncurkan pada tahun 2015 secara serentak di 7 negara, yakni Singapura, Malaysia, Thailand, Taiwan, Indonesia, Vietnam dan Filipina. Sea Group memiliki misi untuk meningkatkan kualitas kehidupan para konsumen dan pengusaha kecil menjadi lebih baik dengan teknologi. Sea Group terdaftar di NYSE (Bursa Efek New York) di bawah simbol SE. Shopee Indonesia sejak 
peluncurannya, mengalami perkembangan yang sangat pesat, bahkan hingga Oktober 2017 aplikasinya sudah didownload oleh lebih dari 43 juta pengguna. Menawarkan one stop mobile experience, Shopee menyediakan fitur live chat yang memudahkan para penjual dan pembeli untuk saling berinteraksi dengan mudah dan cepat.

Shopee memiliki beragam pilihan kategori jenis produk, seperti pakaian Pria, Perlengkapan Rumah, Tas Pria, Hobi \& Koleksi, Makanan \& Minuman, Pakaian Wanita, Fashion Anak, Tas Wanita, Kosmetik, Otomotif, Handphone \& Aksesoris, Ibu \& Bayi, Jam Tangan , Fotografi, Souvenir \& Pesta, Perawatan \& Kesehatan, Sepatu Pria, Aksesoris Fashion, Fashion Muslim, Serba Serbi, Komputer \& Aksesoris, Sepatu Wanita, Elektronik, Perlengkapan Olahraga, dan masih banyak lagi. Tampilan produk yang dijual Shopee cukup menarik dengan dilengkapi fitur chat langsung ke penjual dan review dari pembeli sehingga lebih memudahkan para calon pembeli dalam memilih produk yang akan mereka beli. Shopee memberikan kenyaman belanja dengan harga yang terjangkau untuk semua kategori produk dengan mengedepankan berbagai fitur potongan harga seperti koin Shopee, Kode Promo, Voucher, Paket Diskon untuk penjual dan pembeli, Grup Hemat dan promo lainnya.

Shopee menyediakan sarana yang tepat guna mendukung para penjual online di Shopee, dengan mendaftarkan produk dan mulai berjualan dengan mudah dan meningkatkan popularitas produk jualan serta ikut aktif dalam kampanye dan promosi Shopee. Shopee Seller Centre berguna untuk mengorganisir produk, melacak pengiriman, mengatur pesanan, dan mengukur performa toko online. Para penjual juga bisa membagikan informasi produk di media sosial, seperti Facebook, Twitter, dan Instagram. Strategi penjualan yang baik penjual dapat memperoleh reputasi toko online dengan mengumpulkan rating dan review positif dari para pembeli. Shopee juga menyediakan layanan penjualan dengan gratis tanpa komisi dan tanpa biaya pengunduhan.

Shopee memiliki lebih dari 40 juta pengguna dengan lebih dari tiga juta penjual, dan tiga juta followers sosial media. Pencapaian Shopee adalah hasil dari tiga komitmen utama meliputi Garansi Shopee, Gratis biaya pengiriman, dan Garansi harga termurah. Garansi Shopee berfungsi untuk membangun kredibelitas Shopee di mata pelanggan. Garansi Harga Termurah juga digunakan untuk menarik lebih banyak pembeli. Shopee melakukan kerja sama dengan para seller untuk membuat kesepakatan harga. Ketika pembeli menemukan harga yang lebih mahal dari produk yang dibeli di Shopee, pihak Shopee akan memberikan kompensasi voucher belanja senilai dua kali selisih harga. Garansi Shopee dan Garansi Harga Termurah didukung dengan inisiatif Gratis Biaya Pengiriman yang merupakan salah satu inisiatif Shopee dalam menarik pelanggan.

Strategi pemasaran Shopee adalah untuk para penjual Shopee menyediakan sarana yang tepat untuk mendukung para penjual dalam berjualan di Shopee. Mulai dari mendaftarkan produk dan mulai berjualan hanya dalam 30 detik, serta dalam meningkatkan popularitas produk bisa ikut serta dalam kampanye dan promosi dari shopee. Ada juga Shopee Seller Centre untuk mengorganisir produk, melacak pengiriman, mengatur pesanan, dan mengukur performa toko. Model yang dikembangkan dalam penelitian ini bertumpu pada variabel keamanan, kepercayaan dan privasi terhadap niat bertransaksi secara online di Shopee.

Menurut the theory planned behavior, tindakan individu pada perilaku tertentu ditentukan oleh niat individu tersebut untuk melakukan perilaku. Teori ini menjelaskan tentang niat individu untuk melakukan 
perilaku tertentu (Rekka et al., 2019). Niat merupakan kesediaan konsumen untuk bertransaksi menggunakan sistem e-commerce. Niat dibentuk oleh sikap, norma subjektif, dan kontrol prilaku persepsian. Kepercayaan dalam Theory Planned Behavior akan menjadi konsep dalam sebagai keyakinan yang berdampak pada bertransaksi menggunakan sistem e-commerce. Inti dari the theory planned behavior dan the theory reasoned action, adalah niat individu untuk melakukan perilaku tertentu. Dalam the theory reasoned action dan the theory planned behavior, sikap terhadap perilaku dan norma subyektif dalam perilaku dapat dipengaruhi oleh niat, tapi the theory planned behavior memasukkan unsur kontrol perilaku sebagai faktor tambahan yang mempengaruhi niat konsumen untuk bertransaksi secara online. Aribowo (2013), adanya pengaruh positif trust terhadap niat untuk bertransaksi menggunakan e-commerce.

Niat merupakan suatu keinginan untuk melakukan perilaku. Konsep niat didefinisikan sebagai suatu keinginan untuk melakukan perilaku. Niat tidak selalu statis, niat dapat berubah-ubah dengan berjalannya waktu (Jogiyanto, 2007:29). Novitasari (2014), niat menunjukan kemauan seseorang dalam melakukan pembelian secara online, sehingga, dalam mengukur niat akan dapat memberikan indikasi terhadap perilaku konsumen untuk bertransaksi online. Niat untuk bertransaksi menggunakan sistem $e$ commerce salah satunya dipengaruhi oleh kepercayaan. Penelitian sebelumnya yang telah meneliti mengenai pengaruh kepercayaan terhadap niat untuk bertransaksi menggunakan sistem e-commerce adalah keamanan telah dilakukan. Sularto (2004); McKnight (2008), dan Syaifudin (2013) menemukan kepercayaan pada internet mempengaruhi niat beli konsumen untuk melakukan perilaku.

Niat itu sendiri dipengaruhi sikap terhadap perilaku, norma subyektif yang mempengaruhi perilaku, dan kontrol keperilakuan yang dirasakan. Menurut Azjen (1985), sikap terhadap perilaku merupakan evaluasi positif atau negatif dalam melakukan perilaku. Sikap terhadap perilaku menunjukkan tingkatan seseorang mempunyai evaluasi yang baik atau yang kurang baik tentang perilaku tertentu. Norma subyektif menunjukkan tekanan sosial seseorang untuk melakukan tindakan, sedangkan kontrol keperilakuan yang dirasakan menunjukkan mudahnya atau sulitnya seseorang melakukan tindakan dan dianggap sebagai cerminan pengalaman masa lalu disamping halangan atau hambatan yang terantisipasi. The theory reasoned action juga banyak digunakan dalam penelitian tentang sistem informasi, mengenai penerimaan pengguna dan penerimaan teknologi.

Menurut Rizal (2015), niat untuk membeli merupakan sesuatu yang berhubungan dengan rencana konsumen untuk membeli produk tertentu, serta beberapa banyak unit produk yang dibutuhkan pada periode tertentu. Minat digambarkan sebagai suatu situasi seseorang sebelum suatu tindakan, yang dapat dijadikan dasar untuk memprediksi perilaku atau tindakan tersebut. Minat beli diperoleh dari suatu proses belajar dan proses pemikiran yang membentuk suatu persepsi. Minat beli yang muncul menciptakan suatu motivasi yang terus terekam dalam benaknya, yang pada akhirnya ketika seorang konsumen harus memenuhi kebutuhannya akan mengaktualisasikan apa yang ada didalam benaknya itu. Pembelian yang belum tentu akan dilakukan pada masa mendatang namun pengukuran terhadap minat pembelian umumnya dilakukan guna memaksimumkan prediksi terhadap pembelian aktual itu sendiri (Nurlina, 2017).

Berdasarkan uraian diatas, maka penelitian ini bertujuan pengaruh keamanan, kepercayaan dan privasi terhadap niat konsumen untuk berteransaksi secara online di Shopee di Kota Denpasar Provinsi Bali. 


\section{METODE}

Penelitian ini menggunakan metode kuantitatif dengan pendekatan survei. Penarikan sampel penelitian menggunakan accidental sampling, dengan sampel penelitian sebanyak 110 responden yang merupakan konsumen pengguna E-commerce Shopee di Kota Denpasar Provinsi Bali. Hasil penelitian diolah dengan menggunakan SPSS kemudian dianalisis dengan menggunakan analisis regresi linear berganda.

\section{HASIL DAN DISKUSI}

\section{Deskripsi Variabel Yang Mempegaruhi (X)}

1) Deskripsi Variabel Keamanan (X1)

Tabel 1

Nilai Signifikansi Viaribel Keamanan

\begin{tabular}{|l|c|c|c|c|c|}
\hline & \multicolumn{2}{|c|}{$\begin{array}{c}\text { Unstandardized } \\
\text { Coefficients }\end{array}$} & $\begin{array}{c}\text { Standardized } \\
\text { Coefficients }\end{array}$ & $\mathrm{t}$ & Sig \\
\hline & $\mathrm{B}$ & $\begin{array}{c}\text { Std. } \\
\text { Error }\end{array}$ & Beta & & \\
\hline $\mathrm{C}$ & .459 & .100 & & 4.569 & .000 \\
\hline $\mathrm{X} 1$ & .001 & .000 & 1.072 & 5.340 & .000 \\
\hline
\end{tabular}

Sumber: Olahan Data Penelitian, 2021

Hasil pengujian pada tabel, menunjukkan bahwa variabel keamanan (X1) dengan nilai signifikansi yaitu $0.000<0.05$ berpengaruh langsung terhadap variabel niat bertransaksi secara online (Y).

2) Deskripsi Variabel Kepercayaan (X2)

Tabel 2

Nilai Signifikansi Viaribel Kepercayaan

\begin{tabular}{|l|c|c|c|c|c|}
\hline & \multicolumn{2}{|c|}{$\begin{array}{c}\text { Unstandardized } \\
\text { Coefficients }\end{array}$} & $\begin{array}{c}\text { Standardized } \\
\text { Coefficients }\end{array}$ & $\mathrm{T}$ & Sig \\
\hline & $\mathrm{B}$ & $\begin{array}{c}\text { Std. } \\
\text { Error }\end{array}$ & Beta & & \\
\hline C & .459 & .100 & & 4.569 & .000 \\
\hline X2 & .001 & .000 & .290 & 2.163 & .036 \\
\hline
\end{tabular}

Sumber: Olahan Data Penelitian, 2021

Hasil pengujian pada tabel, menunjukkan bahwa variabel kepercayaan (X2) dengan nilai signifikansi yaitu $0.036<$ 0.05 berpengaruh langsung terhadap variabel niat bertransaksi secara online $(\mathrm{Y})$.
3) Deskripsi Variabel Privasi (X3)

Tabel 3

Nilai Signifikansi Viaribel Privasi

\begin{tabular}{|l|c|c|c|c|c|}
\hline & \multicolumn{2}{|c|}{$\begin{array}{c}\text { Unstandardized } \\
\text { Coefficients }\end{array}$} & $\begin{array}{c}\text { Standardized } \\
\text { Coefficients }\end{array}$ & $\mathrm{T}$ & Sig \\
\hline & $\mathrm{B}$ & $\begin{array}{c}\text { Std. } \\
\text { Error }\end{array}$ & Beta & & \\
\hline C & .459 & .100 & & 4.569 & .000 \\
\hline X3 & 1.256 &. .158 & 1.671 & 7.943 & .000 \\
\hline
\end{tabular}

Sumber: Olahan Data Penelitian, 2021

Hasil pengujian pada tabel, menunjukkan bahwa variabel privasi (X3) dengan nilai signifikansi yaitu $0.000<0.05$ berpengaruh langsung terhadap variabel niat bertransaksi secara online (Y).

\section{Hasil Uji Data Penelitian}

Hasil analisis penelitian ini sudah memenuhi uji persyaratan analisis regresi linear berganda. Data kuesioner yang terkumpul kepada responden telah diuji validitas dan realiabilitasnya sehingga dapat dilanjutkan pada pengujian asumsi klasik yang terdiri dari uji normalitas, uji asumsi non multikolinearitas dan uji asumsi klasik non heteroskesdasitas.

1) Pengaruh Signifikansi Simultan

Hasil pengujian hipotesis menunjukan bahwa adanya pengaruh secara simultan antara keamanan, kepercayaan, dan privasi terhadap niat bertransaksi konsumen. Semakin sering konsumen yang berniat bertransaksi di Shopee membuat pihak Shopee semakin meningkatkan kualitas pelayanan yang diberikan. Hal ini menunjukan bahwa ketiga variabel independen tersebut secara bersama-sama dapat membentuk keinginan untuk bertransaksi secara online. membuktikan bahwa niat bertransaksi dipengaruhi oleh keamanan, kepercayaan, privasi.

Tabel 4

Hasil Uji Signifikansi

\begin{tabular}{|l|c|c|}
\hline \multicolumn{1}{|c|}{ Hipotesis } & Nilai & Keputusan \\
\hline $\mathrm{H}_{0}: \beta_{i}=0$ (tidak terdapat pengaruh & $\mathrm{F}=24,057$ & $\mathrm{H}_{0}$ ditolak, \\
yang signifikan antara variabel $\mathrm{X}_{1}$, sig $=0,000$ & \\
$\mathrm{X}_{2}$, dan $\mathrm{X}_{3}$ terhadap, variabel $\mathrm{Y}$ ) & $\mathrm{F}_{\text {tabel }}=2,69$ & \\
$\mathrm{H}_{\mathrm{a}}: \beta_{i} \neq 0$ (terdapat pengaruh & & \\
antara variabel $\mathrm{X}_{1}, \mathrm{X}_{2}$, dan $\mathrm{X}_{3}$ & & $\mathrm{H}_{\mathrm{a}}$ diterima \\
terhadap variabel $\mathrm{Y}), \alpha=0,05$ & & \\
\hline
\end{tabular}

Sumber : Olahan Data Penelitian, 2021 
2) Pengaruh Signifikansi Parsial

Hasil pengujian hipotesis menunjukan bahwa variabel keamanan $\left(\mathrm{X}_{1}\right)$, kepercayaan $\left(\mathrm{X}_{2}\right)$, dan privasi $\left(\mathrm{X}_{3}\right)$,memiliki nilai signifikan t yang lebih besar dari Sig.a $(0,05)$ sehingga dapat dikatakan bahwa variabel tersebut memiliki pengaruh yang signifikan secara parsial terhadap niat bertransaksi secara online di Shopee.

3) Hasil Koefisien Determinasi

Hasil perhitungan analisis regresi linier berganda menunjukkan kemampuan model dalam menjelaskan pengaruh variabel independen terhadap variabel dependen adalah besar, hal tersebut dapat dilihat pada nilai Adj. R. Square (R2) yaitu sebesar 0,876 $(87,6 \%)$. Model regresi yang digunakan telah mampu menjelaskan pengaruh variabel keamanan (X1), kepercayaan (X2), privasi (X3) terhadap niat bertransaksi secara online di di Shopee sebesar 87,6\%, sedangkan sisanya sebesar $16,4 \%$ dijelaskan oleh variabel-variabel lain yang tidak termasuk dalam penelitian ini.

\section{Pengaruh Variabel (X1) Keamanan Terhadap Niat Bertransaksi Online $E$ - Commerce Shopee (Y)}

Keamanan adalah kemampuan toko online adalam melakukan pengontrolan dan penjagaan keamanan atas transaksi data. Jaminan keamanan berperan penting dalam pembentukan kepercayaan dengan mengurangi perhatian konsumen tentang penyalahgunaan data pribadi dan transaksi data yang mudah rusak. Ketika level jaminan keamanan dapat diterima dan bertemu dengan harapan konsumen, maka seorang konsumen mungkin akan bersedia membuka informasi pribadinya dan akan membeli dengan perasaan aman (Ardianto Kusuma, 2016). Keamanan atau security sebagai kemampuan toko online dalam melakukan pengontrolan dan penjagaan keamanan atas transaksi data. Variabel keamanan ini dapat diukur dengan menggunakan indikator- indikator yang dirujuk dari penelitian (Fachrizi, 2016), adalah jaminan kemanan dan kerahasiaan data.

Studi empiris sangat terbatas pada keamanan, Miyazaki dan Fernandez (2001) menemukan keamanan sistem dihubungkan dengan tingkat tarif dari produk online yang dibeli oleh konsumen, keamanan dan privasi secara positif dihubungkan dengan kemungkinan pembelian secara online. Pengujian peran persepsi resiko dalam hubungan antara keamanan dan privasi berhubungan dengan dan niat bertransaksi secara online. Ada hubungan antara kehadiran statemen keamanan dan privasi dan resiko yang ditemukan (Miyazaki, 2001). Konsumen yang merasa aman terhadap lingkungan internet secara keseluruhan akan cenderung percaya terhadap website yang menyediakan pelayanan e-commerce dibandingkan dengan orang yang merasa bahwa internet tidak aman karena tidak yakin adanya perlindungan yang aman (Gefen et al., 2003).

Hasil penelitian mengenai pengaruh keamanan terhadap niat bertransaksi online menunjukkan bahwa variabel keamanan mempunyai pengaruh positif dan signifikan terhadap niat bertransaksi secara online di Shopee, sehingga apabila terjadi kenaikan pada variabel keamanan, maka akan meningkatkan niat bertransaksi secara online di e-commerce Shopee. Shopee memperhatikan sistem keamanan guna menjaga kepercayaan dan kepuasan pelanggannya. Pelanggan juga dianjurkan agar jangan pernah memberitahukan e-mail dan kata sandi login di Shopee kepada siapapun. Shopee menjaga kerahasiaan informasi data pribadi pelanggan dengan sistem yang baik. Shopee harus selalu memperbaruhi sitem keamanan agar tidak terjadi hal yang diinginkan seperti data rusak, terserang ancaman virus maupun dibajak oleh pihak lain. 
Pengaruh Variabel Kepercayaan (X2) Terhadap Niat Bertransaksi Online $E$ Commerce Shopee (Y)

Komponen yang paling penting dari pembelian online adalah kepercayaan dari pelanggan ke toko online itu sendiri (Giantari et al., 2013). Keinginan serta harapan konsumen agar tercipta kepercayaan pelanggan yang akhirnya dapat menimbulkan niat membeli (Adji dan Semuel, 2014). Kepercayaan konsumen terhadap perusahaan merupakan suatu aset yang tak ternilai bagi perusahaan (Maima, 2012).

Sam dan Tahir (2009) dalam penelitiannya menunjukkan bahwa kepercayaan merupakan faktor yang berpengaruh paling langsung dalam memprediksi niat pembelian kembali secara online. Lebih lanjut, Sam dan Tahir menyatakan adanya hubungan yang signifikan pada kepercayaan terhadap niat pembelian online. Hasil penelitian yang dilakukan Sam dan Tahir sejalan peneltian yang dilakukan oleh Nusarika dan Purnami (2015) menunjukan bahwa adanya hubungan positif antara kepercayaan dengan niat pembelian konsumen.

Pengujian yang di lakukan oleh Giantari et al. (2013) terkait variabel kepercayaan terhadap variabel niat membeli online mendapatkan hasil positif dan signifikan. Becerra dan Korgaonkar (2011) menemukan bahwa kepercayaan berkontribusi positif terhadap keberhasilan transaksi online.

Akbar (2009), bahwa kepercayaan memiliki peran yang penting dalam mempengaruhi komitmen, semakin populer website online shopping tersebut maka tingkat kepercayaan pembeli kepada website online shoping tersebut semakin tinggi. Pembelipun akan semakin yakin dan percaya terhadap reabilitas website, bahwa website tersebut nyata keberadaanya dan benar-benar ada. Kepercayaan dibentuk oleh konsumen yang didasarkan pada informasi yang tersedia tentang toko online. Kepercayaan toko online dapat menghasilkan suatu sikap yang baik oleh konsumen dan mungkin juga meningkatkan sikap secara tidak langsung dengan menurunkan persepsi resiko.

Dalam sistem e-commerce, kepercayaan pengguna tentang suatu toko online mungkin ditangkap oleh kepercayaan dan persepsi resiko. Sikap salah satu yang baik atau kurang baik. Suatu sikap yang baik akan membentuk niat untuk bertransaksi secara online, kemudian diikuti oleh niat perilaku nyata dalam membeli dari toko online. Kepercayaan dibentuk oleh konsumen yang didasarkan pada informasi yang tersedia tentang toko online. Kepercayaan pada suatu toko online dapat menghasilkan suatu sikap yang baik oleh konsumen dan mungkin juga meningkatkan sikap secara tidak langsung dengan menurunkan persepsi resiko (Jarvenpaa et al., 1999).

Ridings et al. (2002) meneliti mengenai penyebab dan pengaruh kepercayaan (trust) pada komunitas maya. Hasil dari penelitian ini menjelaskan bahwa kepercayaan (trust) merupakan prediktor yang signifikan pada keinginan anggota komunitas maya untuk saling berbagi dan saling memperoleh informasi. Perhatian, keterbukaan, dan watak yang baik dapat membangun kepercayaan. Kepercayaan merupakan aspek terpenting dalam komunitas maya. Kepercayaan di antara para anggota komunitas maya akan semakin besar apabila mereka saling mengetahui secara personal.

Kepercayaan selalu dianggap sebagai faktor yang paling penting, yang merangsang membeli melalui internet, seperti yang telah diakui secara positif mempengaruhi niat konsumen online untuk membeli (Kevin 2016). Hal ini juga dianggap sebagai penghalang jangka panjang, yang menghalangi potensi beli online, lebih khusus ketika bisnis dalam kondisi yang tidak mementu. Oleh karena itu, Kepercayaan adalah pusat untuk semua transaksi ekonomi, 
baik yang dilakukan di outlet ritel di dunia offline ataupun melalui internet. Ini merupakan aspek penting yang mempengaruhi minat pelanggan untuk berbelanja secara online. Penelitian menurut Wenny (2015), bahwa faktor yang membentuk kepercayaan seseorang terhadap keputusan pembelian konsumen $e$ - commerce adalah kemampuan (ability), kebaikan hati (benevolence), dan integritas (integrity).

Hasil penelitian mengenai pengaruh kepercayaan terhadap niat bertransaksi online menunjukkan bahwa variabel kepercayaan mempunyai pengaruh positif dan signifikan terhadap niat bertransaksi secara online di $E$ Commerce Shopee, sehingga apabila terjadi kenaikan pada variabel kepercayaan, akan meningkatkan niat bertransaksi secara online di e-commerce Shopee. Shopee selalu memenuhi janji kepada ppelanggannya dengan memberikan rasa aman, terjaganya kerahasiaan informasi data pengguna, sehingga Shopee selalu meningkatkan prioritas kepercayaan konsumen. Shopee selalu memberikan informasi jujur kepada penggunanya. Shopee berusaha menjaga keamanan dengan menggunakan sistem veriefed member dan ketika melakukan penipuan akan langsung di banned oleh pihak Shopee. Shopee selalu memenuhi tanggung jawab dan jaminan kepada para konsumen. Bila ada keluhan akan secara cepat direspon dan ditindak lanjuti. Shopee memberikan jaminan perlindungan hukum sesuai dengan peraturan hukum yang mengatur tentang IT dan E-Commerce kepada konsumen.

\section{Pengaruh Variabel Privasi (X3) Terhadap Niat Bertransaksi Online E-Commerce Shopee (Y)}

Privasi merupakan faktor penting membentuk kepercayaan konsumen terhadap niat bertransaksi secara online. Privasi berkaitan menganai informasi dan data pribadi konsumen harus dijaga keamananya oleh pengelola situs web. Privasi mengenai data personal konsumen harus dikontrol dengan baik sehingga, konsumen merasa nyaman dimana setiap data konsumen akan dijaga kerahasianya. Konsumen dapat menggunakan hak untuk mencegah pemrosesan tersebut dengan menghubungi layanan info yang tersedia di situs Shopee. Informasi privasi mengacu pada individu, kelompok, atau institusi untuk menentukan diri mereka sendiri dan bagaimana tentang luasnya informasi tentang apa yang dikomunikasikan pada orang lain (Malhotra, et al 2004). Perhatian informasi privasi mengacu pada suatu pandangan hubungan individu dalam konteks informasi privasi.

Privasi dapat dipengaruhi oleh beberapa faktor kondisi ekternal seperti industri, budaya, dan hukum. Konsep privasi digambarkan sebagai suatu kemampuan individu untuk mengendalikan informasi pribadi yang telah diperoleh. Privasi digunakan sebagai kebenaran seseorang untuk menjadi dirinya sendiri untuk mengendalikan aliran dan pemberitahuan informasi tentang orang lain atau dirinya sendiri (Warren dan Brandies, 1980).

Secara umum privasi mengacu pada perlindungan informasi pribadi. Chau., et al (1999) mendefinisikan adalah hak individu untuk menjadikan dirinya sendiri dengan mempertimbangkan beberapa dimensi privasi seperti, prilaku, komunikasi, dan data pribadi. Dalam internet, privasi mempengaruhi aspek seperti distribusi, atau penggunaan non-autorised informasi pribadi (Wang et al., 1998). Kapasitas pertumbuhan teknologi baru untuk mengolah informasi, plus kompleksitas menjadikan privasi isu penting. Fakta ini semakin meningkatkan kecurigaan konsumen seperti bagaimana data pribadi dikumpulkan diproses dalam transaksi online (Flavio dan Gunalu, 2006).

Hasil penelitian mengenai pengaruh privasi terhadap niat bertransaksi online menunjukkan bahwa variabel privasi mempunyai pengaruh positif dan signifikan 
terhadap niat bertransaksi secara online di Shopee, sehingga apabila terjadi kenaikan pada variabel privasi maka akan meningkatkan niat bertransaksi secara online di Shopee. Shopee menunjukkan kepedulian terhadap informasi pribadi pengguna, pengguna diberikan hak meminta Shopee untuk tidak memproses data pribadi pengguna dengan tujuan pemasaran. Shopee telah menjaga informasi pribadi pengguna dengan memberikan jaminan hukum yang mengatur perdangangan e-commerce yakni UU No. 11 Tahun 2008 tentang Informasi dan Transaksi Elektronik. Shopee menyimpan kerahasiaan informasi data pribadi pengguna di server Shopee yang berlokasi di pusat data yang ditunjuk oleh Shopee.

\section{KESIMPULAN}

Penelitian ini menunjukkan bahwa variabel keamanan, kepercayaan dan privasi memiliki pengaruh simultan signifikan terhadap variabel niat bertransaksi secara online di Shopee di e-commerce Shopee di Kota Denpasar Provinsi Bali dan variabel keamanan, kepercayaan dan privasi memiliki pengaruh parsial signifikan terhadap variabel niat bertransaksi secara online di e-commerce Shopee di Kota Denpasar Provinsi Bali. Artinya, semakin tinggi tingkat keamanan, kepercayaan, privasi yang dilakukan oleh $e$ commerce Shopee maka semakin tinggi pula niat bertransaksi online di e-commerce Shopee, dan sebaliknya semakin rendah tingkat keamanan, kepercayaan, privasi yang dilakukan oleh e-commerce Shopee maka semakin rendah pula niat bertransaksi online di e-commerce Shopee. Oleh karena itu untuk meningkatkan niat bertransaksi online di ecommerce Shopee, maka pihak perusahaan memperhatikan faktor-faktor keamanan, kepercayaan, dan privasi dalam menerapkan dan mengembangkan transaksi e-commerce.

\section{REFERENSI}

Adji, J. \& Semuel, H. (2014). Pengaruh Satisfaction dan Trust Terhadap Minat Beli Konsumen (Purchase Intention) di Starbucks The Square Surabaya. Jurnal Manajemen Pemasaran Petra, 2(1), 110.

Alwafi, Fachrizi. \& Magdani, Rizal Hari. (2016). Pengaruh Presepsi Keamanan, Kemudahan Bertransaksi, Kepercayaan Terhadap Toko dan Pengalaman Berbelanja Terhadap Minat Ali Secara Online Pada Situs Jual Beli Tokopedia.Com. E-jurnal Universitas Diponegoro, 5(2), 1-15.

Anandita, Florentinus., B., A., \& Sumarno, Dwi Saputra. (2015). Analisis Pengaruh Kepercayaan, Keamanan, dan Presepsi Akan Risiko Terhadap Keputusan Pembelian Melalui Situs Jejaring Sosial. Jurnal Ekonomi dan Kewirausahaan, 15(2), 203-210.

Ananta, Riza. (2006). Penerapan e-Commerce Dalam Kegiatan Pemasaran Produk Elektronik di Kota Malang. Skripsi. Jurusan Manajemen Konsentrasi pemasaran Fakultas Ekonomi Universitas Brawijaya Malang.

Ajzen, I. (1985). From Intentions do Actions: A Theory of Planned Behavior. Action Control: From Cognition do Behavior, J. Kuhl and J. Beckman, def., Springer Verlag, New York, 11-39.

Ardianto Kusuma. (2016). Analisis FaktorFaktor Yang Berpengaruh Terhadap Keputusan Pembelian Secara Online di Website Tokopedia. Universitas Islam Indonesia Yogyakarta.

Aribowo, Dwi., P., J., \& Mahendra Adhi Nugroho. (2013). Pengaruh Trust dan Perceived of Risk Terhadap Niat Untuk Bertransaksi Menggunakan E- commerce. Jurnal Nominal, 2(1).

Cooper \& Schindler. (2003). Business Research Methods. International Edition. 
Fauziah, D. N. \& Wulandari, D. A. N. (2018). Pengukuran Kualitas Layanan Bukalapak.com Terhadap Kepuasan Konsumen dengan Metode Webqual 4.0. Jurnal Ilmu Pengetahuan Dan Teknologi Komputer, 3(2), 173-180.

Gefen, D. (2002). Customer Loyalty in ECommerce. Journal of the Association for Information Systems, 3:27-51.

Ghozali, Imam. (2006). Aplikasi Analisis Multivariate dengan Program SPSS (Edisi $\mathrm{Ke}$ 4). Semarang. Badan Penerbit Universitas Diponogoro.

Giantari, I.G.A.K., Zain, D., Rahayu, M. \& Solimun. (2013). The Role of Perceived Behavioral Control and Trust as Mediator of Experience on Online Purchasing Intentions Relationship A Study on Youths in Denpasar City (Indonesia). International Journal of Business and Management Invention, 2(1), 30- 38.

Gujarati, Damodar. (2001). Ekonometrika Dasar. Jakarta: Erlangga.

Hoffman, D.L., Novak, T.P. and Peralta, M. (1999). Building consumer Trust online Communications of the ACM, 42(4), 8095.

Jogiyanto, H. M. (2007). Sistem Informasi Keperilakuan. Yogyakarta: Erlangga.

Kevin \& Puspita. (2016). Pengaruh Verifikasi Keamanan Online Terhadap Kepercayaan dan Minat Beli Konsumen. Fakultas Ekonomi dan Bisnis. Universitas Telkom, 3(3).

Kotler, Philip. (2007). Manajemen Pemasaran Jilid I Edisi Kedua Belas. Jakarta: PT. Indeks.

Maima, K.R., (2012). Analisis Pengaruh Kepercayaan Pelanggan dan Kualitas Pelayanan Terhadap Sikap Pelanggan dan Implikasinya Terhadap Keputusan Pembelian Ulang (Studi Kasus Pada CV.Mukti Manunggal Semarang). Diponegoro Business Review, 1(1), 17.
Mangkunegara, Anwar Prabu. (2002). Manajemen Sumber Daya Manusia. Bandung.

Mao, D., 2010. A Study of Consumer Trust in Internet Shopping And the Moderating Effect of Risk Aversion in Mainland China. Journal Manajemen, 1(1), 1-50.

Muhsin, A., \& Zuliestiana, D. A. (2017). Analisis Pengaruh Kualitas Website (Webqual) 4.0 Terhadap Kepuasan Pengguna Bukalapak Di Kota Bandung. E-Proceeding of Management, 4(3), $18-19$

Mukherjee, A., \& Nath, P. (2003). A Model of Trust in Online Relationship Banking, International Journal of Bank Marketing, 21 (1), 5-15.

Nazar, M. Rafki dan Syahran. (2008). Pengaruh Privasi, Keamanan, Kepercayaan, dan Pengalaman Terhadap Niat untuk Bertransaksi Secara Online. Simposiun Nasional Akuntansi (SNA) Ke XI Pontianak, 22-23 Juli 2008.

Novitasari, S \& Baridwan, Zaki. (2013). Pengaruh Kepercayaan, Persepsi Risiko, Persepsi Manfaat, Dan Persepsi Kontrol Perilaku Terhadap Niat Penggunaan Sistem E-Commerce. JIMFEB, 1(1).

Nugroho, A. K., \& Sari, P. K. (2016). Analisis Pengaruh Kualitas Website Tokopedia Terhadap Kepuasan Pengguna Menggunakan Metode Webqual 4 . 0 EProceeding of Management, 3(3), 2930 2937.

Nusarika, L.A.K. \& Purnami, N.M., 2015. Pengaruh Persepsi Harga, Kepercayaan dan Orientasi Belanja Terhadap Niat Beli Secara Online (Studi pada Produk Fashion Online di Kota Denpasar). E-Jurnal Manajemen Unud, 4(8), 2380-2406.

Nurlina. 2017. Pengaruh E-Service Quality dan Kepercayaan Online Terhadap Minat Pembelian Toko Online di Tokopedia. Komputerisasi Akuntansi, Politeknik LP3I Jakarta. Jurnal Lentera Bisnis, $6(2)$. 
Ridings, C. M., Gefen, D., \& Arinze, B. (2002). Some Antecedents and Effect of Trust in Virtual Communities.Journal of Strategic Information Systems, 271295.

Sam, M.F.M. \& Tahir, M.N.H. (2009). Website Quality and Consumer Online Purchase Intention of Air Ticket. International Journal of Basic \& Applied Sciences IJBAS-IJENS, 9(10), 4-9.

Saputra, Ahmad (2017). Analisis Pengaruh Penerapan e-commerce dan Kualitas Pelayanan terhadap Kepuasan Konsumen. Jurnal Manajemen Bisnis STIE IBBI, 27(1), 53-62.

Smith, H. J., Milberg, S. J., and Burke, S. J. (1996). Information Privacy: Measuring Individuals 'Concerns About Organizational Practices."Misquarterly, 20(2), 167-196.

Rekka, R., Totanan, C., Sudirman, dan Mayapada, A. G. (2019). Analisis Faktor Penerimaan dan Penggunaan Software Accurate Dalam Perspektif Technology Acceptance Model (Studi Empiris pada Mahasiswa Program Studi S1 Jurusan Akuntansi Fakultas Ekonomi Universitas Tadulako). Jurnal Akun Nabelo: Jurnal Akuntansi Netral, Akuntabel, Objektif, 1(2), 81-91.

Rofiq, (2007). Pengaruh Dimensi Kepercayaan (Trust) terhadap Partisipasi Pelanggan ECommerce. (Tesis Universitas Brawijaya). Wenny, dkk. (2015). Analisis Pengaruh Harga dan Kepercayaan Terhadap Minat Beli dan Implikasinya pada Keputusan Pembelian Produk Secara Online Melalui Media Sosial Facebook (Studi Kasus Di Forum Jual-Beli Kota Pangkalpinang). STIE-IBEK Bangka Belitung. Jurnal Ilmiah Progresif Manajemen Bisnis (JIPMB), $3(2)$. 